\title{
Present in Love: Rethinking Barth on the Divine Perfections
}

\author{
Ian A. McFarland
}

\begin{abstract}
While Karl Barth's identification of love and freedom (in that order) as the fundamental divine perfections was intended to eliminate any gap between God as revealed and God's eternal being, Barth's equation of divine freedom with decision fatally compromises this aim by reintroducing the spectre of a 'hidden God' behind the God revealed in Jesus. Moreover, it exacerbates a worryingly anthropomorphic model of divine action, already pronounced in older orthodox theologies, that is ill-suited to upholding the causal integrity of the created order. Substituting presence for freedom as the foundational perfection paired with (and used to interpret) divine love maintains the benefits of Barth's relative prioritization of love while avoiding the problems that accompany the interpretation of divine freedom as decision. Specifically, it provides a model of divine action in which permission rather than decision emerges as the fundamental mode of willing whereby by God brings the world into being and sustains it in existence.
\end{abstract}

Keywords: Karl Barth, freedom, love, permissive will, presence

Although there is a long tradition of describing Karl Barth's theology as 'neoorthodox', it does not take much familiarity with his work to recognise that his Church Dogmatics is anything but a repristination of the old orthodoxy of Reformed Scholasticism. As reflected in the vigorous critique to which his work was subjected in 
his own lifetime by more conservative Reformed theologians (for example, G. C.

Berkouwer in Europe and Cornelius van Til in the U.S.), Barth's theology is marked by significant revisions of classical Reformed positions, most famously in the doctrine of election developed in Church Dogmatics II/2, but running straight through his magnum opus from the wholesale rejection of natural theology in volume I to the sacramentology of volume IV. In light of these realities, Bruce McCormack's characterisation of Barth as 'orthodox and modern' (that is, 'seeking to understand what it means to be orthodox under the conditions of modernity') seems a much better way of describing both how Barth conceived his task as a theologian and the kind of theology he produced. ${ }^{1}$

In this paper I examine one instance of Barth's revision of classical Reformed (and, for that matter, Lutheran and Catholic) thinking that in my view does not go far enough: his claim that the two primary divine attributes or perfections are love and freedom. The innovation here is clear: in defining the most fundamental divine perfections, Barth introduces love before freedom in order to challenge what he sees as a standing problem in traditional divine ontologies: divorcing God's (eternal) being from God's (contingent) acts in a way that generates the spectre of an inscrutable Deus absconditus behind the God revealed in Jesus of Nazareth. ${ }^{2}$ My contention is that while these intentions are laudable, the way Barth handles the category of divine freedom fatally handicaps his efforts to fulfil them. I will argue that Barth's aims may be

\footnotetext{
${ }^{1}$ Bruce L. McCormack, Orthodox and Modern: Studies in the Theology of Karl Barth (Grand Rapids, MI: Baker Academic, 2008), 17.

${ }^{2}$ As with the phrase 'classical theism' in other contexts, the category of 'traditional divine ontologies' is open to the charge of inaccuracy by way of sweeping generalization. In light of such concerns, it is important to note that while Barth sees the problem of abstracting God's being from God's acts as rooted in conventions that stretch back to the patristic era, the primary object of criticism in Barth's account of divine perfections is his own tradition of post-Reformation Protestantism. See especially the 'small print' excursus in Karl Barth, Church Dogmatics [hereafter $C D], 13$ vols., ed. and trans. G. W. Bromiley and T. F. Torrance (Edinburgh: T \& T Clark, 1956-1975), II/1, 337-41; cf. 261, 269-70, 287-97.
} 
achieved more effectively if presence replaces freedom as the foundational perfection paired with (and used to interpret) love. It is my contention that characterising God as 'the One who is present in love' maintains Barth's relative prioritisation of love among the divine perfections while avoiding the anthropomorphic model of divine action that accompanies Barth's interpretation of divine freedom as decision. Specifically, I argue that when God is understood as the One who is present in love, permission rather than decision emerges as the fundamental mode of willing whereby God both brings the world into being and sustains it in existence. In this way, my critique of Barth serves as a jumping-off point for a constructive theological proposal on divine ontology and its implications for a Christian account of God's relationship to the world.

\section{Barth on Divine Freedom}

The centrality of love and freedom for Barth's divine ontology is evident throughout his treatment of 'The Reality of God' in volume II/1 of the Church Dogmatics, especially in his division of God's attributes into the perfections of divine love (viz., grace, holiness, mercy, righteousness, patience, and wisdom) on the one hand, and the perfections of divine freedom (viz., unity, omnipresence, constancy, omnipotence, eternity, and glory) on the other. As Barth himself notes, this twofold division is well established in the western theological tradition, although typically described using other terminological pairings (for example, communicable and incommunicable, relative and absolute, moral and metaphysical) rather than Barth's language of love and freedom. Where Barth diverges from the tradition is therefore neither in the essential content of his primary categories, nor in the perfections associated with them, but rather in the sequence in which he presents them. For whereas earlier 
theologians gave pride of place to the 'incommunicable' or 'absolute' perfections of freedom - God's unity, omnipresence, and omnipotence - Barth priortises the 'communicable' or 'relative' perfections of love. In short - and in line with his decision to begin his dogmatics with the Trinity rather than a treatise de Deo uno - Barth adopts this sequence to show that the concrete and personal trump the abstract and metaphysical in matters of divine ontology. Indeed, even before his detailed analysis of the divine perfections, Barth signals this shift is in emphasis in his summary characterisation of God as 'the One who loves' - first - 'in freedom' - second. ${ }^{3}$

Barth defends this sequence on the grounds that the converse, however well established in western dogmatics, effects 'a separation between a God in Himself and a God for us, in which the essential being of God' is associated with 'his sovereign freedom and the perfections proper to it...while the love of God and its perfections....are treated nominalistically or semi-nominalistically as a question of mere economy'. Against this position, Barth argues that because God's being as love is rooted in God's own triune form of existence, it cannot be interpreted in purely economic terms; and on just the same grounds he insists that there is no basis for supposing that the so-called 'incommunicable' attributes provide any more insight into the character of the divine being than the 'communicable' ones do. Barth thus rejects the idea that the perfections of love refer primarily to what we perceive of God in history and the perfections of freedom to transcendent qualities that we cannot see, as though God were "first and properly the impersonal absolute, and only secondarily, inessentially and in His relationship ad extra

\footnotetext{
${ }^{3}$ Barth, $C D$, II/1, 322 (emphasis added) and passim. To be sure, Barth insists that God's love and freedom are inseparable, such that turning from the first to the second does not involve a change in subject matter, but simply ensures that the love in question is understood to specifically and uniquely God's by attending to its grounding in the divine being. See $C D$ II/1, 298-9.

${ }^{4}$ Ibid., 345 .
} 
the personal God of love'. ${ }^{5}$ Instead, he insists that the God we come to know in Jesus Christ is the Trinity and so eternally loving in God's self quite apart from God's works ad extra. He concludes that although there is 'full reciprocity' between love and freedom in God, the relative priority of love 'obtains even in the full reciprocity, not signifying a difference of value between the two aspects of divinity, but the movement of life in which God is God, corresponding exactly to His revelation of Himself as God'. 6

In all of this Barth's position is theologically compelling, and yet there is a certain inconsistency in his presentation that threatens to subvert the sequence he defends, and which suggests a more serious problem that cannot be addressed in the terms Barth proposes. This inconsistency emerges at the very beginning of his account of the divine perfections when in the first subsection of $\S 28$ of the Church Dogmatics ('The Being of God in Act') Barth undertakes a preliminary review of divine ontology, the aim of which is to rule out any division between being and act in God. Once again, his aim here is to block the idea of an unknown (and unknowable) divinity behind the God revealed in God's acts by insisting that the identity of being and act in God is not dependent on any opera ad extra, since 'God is in Himself free event, free act and free life' quite apart from creation. ${ }^{7}$ Yet the result of this move is that before Barth gets to his explicit treatment of the categories of divine love and freedom, priority has already been given to freedom as ontologically foundational. To be sure, this preliminary analysis of God's being-in-act is presented by Barth as purely formal, to be filled in materially by the specification that this act is love; nevertheless, the fact that freedom is the initial as well as final note sounded in Barth's discussion of divine being has the rhetorical effect of making it the

\footnotetext{
${ }^{5}$ Ibid., 348-349.

${ }^{6}$ Ibid., 350.

${ }^{7}$ Ibid., 264.
} 
dominant theme. Despite Barth's intentions, the equation of freedom with selfdetermination, and the corresponding emphasis on decision as the mode of divine being, moves the focus inexorably away from love. And this prioritisation is only intensified when Barth goes on to develop his doctrine of election in volume II/2, where he ventures the claim that God's 'being is decision' not only in God's works ad extra but preeminently 'in His inward activity and being', such that God's work in and with creation 'is a proclamation of the decision in which in Himself $\mathrm{He}$ is who He is'. ${ }^{8}$ So it is that for Barth God's freedom is ever loving and gracious, but, more fundamentally still, it is free. ${ }^{9}$

In all this it is arguably just Barth's efforts - again, laudable in themselves - to eliminate any gap between divine being and act that betrays him. Barth defends his claims about God's freedom as simply an updated form of the traditional Christian affirmation of divine aseity, but the shift in terminology is far more portentous than Barth admits. ${ }^{10}$ For while the 'a' of aseity is not etymologically an alpha privative, the claim that God is a se - 'from God's self' - arguably functions as a negative attribute; that is, its principal purpose is to deny that God is dependent on any other reality. Yet on Barth's actualist interpretation of aseity as freedom, the term becomes a descriptive statement about God's self-generation through 'His own conscious, willed and executed decision' and thereby acquires a much more cataphatic character. ${ }^{11}$ It is certainly not Barth's intention thereby to promote a theological voluntarism. On the contrary, Barth's whole

\footnotetext{
${ }^{8}$ Barth, $C D$ II/2, 175 (emphasis added); cf. $C D$ II/1, 271-272. For all the emphasis rightly placed on Barth's innovations in Church Dogmatics II/2, this tendency is already visible in CD I/1: 'Godhead in the Bible means freedom, ontic and noetic autonomy.... It is thus, as the One who is free, as the only One who is free, that God has lordship in the Bible' (307).

${ }^{9}$ For the equation of freedom with self-determination, see Barth, $C D$ II/1, 302.

10 'By freedom we denote what was called in the theology of the Early Church the aseitas Dei' (Ibid., 302). While this explicit identification comes only in the subsection 'The Being of God in Freedom' that follows the discussion of God's being as love, the same issue (though without explicit reference to the term 'aseity' - except in the volume's index) is raised at the conclusion of 'The Being of God in Act'.

${ }^{11}$ Ibid., 271.
} 
point is to argue that God's freedom is disclosed in God's being for us and therefore is not to be understood as some ontological reserve lying behind that being. That is, he wishes to insist that there is nothing more fundamental to divine ontology than the good news revealed in Jesus - no gap between God's act and God's being, no Deus absconditus hovering behind the Deus revelatus. But the way Barth develops his account of divine being ultimately casts love as a consequence of divine decision rather than as the ground of all God's deciding. Quite against Barth's intention, freedom creeps into a position of relative priority: for if God's love is rooted in God's freedom - in God's decision - then the conclusion seems unavoidable that God might have decided to be otherwise than loving. ${ }^{12}$

\section{The Problem with Freedom as a Foundational Divine Perfection}

Why should freedom be viewed as a foundational divine perfection? Unlike love, it is not explicitly predicated of God in Scripture. This is certainly not to deny that freedom is a biblical concept, but only to note that it is typically presented as that which God achieves for human beings rather than an attribute of the divine being in itself. God frees the Israelites from bondage, and establishes a covenant that has as one of its defining features an ongoing cycle of liberation (Lev. 25:28-33; Deut. 15:1-9). Jesus explicitly identifies his own calling with this tradition at the outset of his public ministry (Luke 4:18-19), through which he frees us from captivity to sin, death, and the devil (see John 8:32-36; cf. Acts 13:39; 2 Cor. 3:17). Freedom, in short, is what God give to us, so that (as Paul reminds the Galatians) now that we have been set free, we are not to submit again to the yoke of slavery (Gal. 5:1). And so it continues in theologies throughout the

\footnotetext{
${ }^{12}$ Pace Bruce McCormack (who I think has accurately characterised the trajectory of Barth's thought in this area), I do not think it helps to specify that for Barth the divine love is an eternal decision (see Orthodox and Modern, 271; cf. 192), for the priority of decision (freedom) over love remains.
} 
patristic, medieval, and Reformation periods. That freedom should be transposed from this soteriological register to become a defining characteristic of divinity is a peculiarly modern development. ${ }^{13}$

This is certainly not to deny that God is free. There are important dogmatic reasons for insisting on divine freedom relating both to God's eternal being and to God's economic activity. Immanently, to say that God is free is to deny that God is relative to or dependent on any other reality. And with respect to the economy, the affirmation of divine freedom secures the point that God's work of creation, redemption, and glorification is truly gracious - a matter of gift rather than necessity. In both cases, however, freedom functions primarily as a negative category; that is, it rules out conceiving divine being as in any way dependent and divine action as in any way compelled rather than providing positive content to divine ontology. Nor do I have any interest in denying that God decides. Both testaments are replete with characterisations of God's saving work as a matter of decision (e.g., Gen. 18:19; Deut. 4:37; 7:6-7; 10:15; 14:2; 18:5; Pss. 33:12; 105:6; 135:4; Isa. 41:8-9; 43:20; 44:1-2; 45:4; Ezek. 20:5; Mark 13:20; Acts 10:41; 13:17; Rom. 11:15; 1 Cor. 1:27-28; 1 Thess. 1:4; Jas. 2:5; 1 Pet. 2:9); but it is one thing to narrate God's saving work in history in this way as a means of affirming the gracious character of election and another to equate decision with the divine being in eternity. The content of the divine will must be rooted in God's being, but (pace

\footnotetext{
${ }^{13}$ Katherine Sonderegger concurs that the 'transposition of biblical language [on divine transcendence] from the idiom of idolatry to that of freedom belongs most properly to the modern era of the Christian West, the era of Enlightenment and its legacy', though she herself goes beyond even Barth in valorising freedom as 'the foundation of all divine predication'. Katherine Sonderegger, The Doctrine of God, vol. 1 of Systematic Theology (Minneapolis, MN: Fortress Press, 2015), 27.
} 
Barth) the two cannot be equated without muddying the distinction between Creator and creation. $^{14}$

In sum, God is without question free in that God is not constrained or compelled by any factor either external or internal to the divine being. But move from this negative point to a positive characterisation of God's willing as decision falls into an unhelpful anthropomorphism, as though, for example, God's creating the world were analogous to my decision to make something or other (say, a cake, a table, or a novel). The two 'decisions' are profoundly disanalogous. Aside from the fact that my creating invariably makes use of, and thus is constrained by, pre-existing materials (whether flour and sugar, wood and glue, or words and ideas) as God's is not, my creation, precisely as a matter of 'decision', involves actualising one set of possibilities over others (chocolate rather than carrot cake, a round rather than a square table, a romance instead of a satire). God's creating isn't like that. God creates from nothing; that is, God is the only antecedent condition of the world's existence. It follows that the divine work of creation is not properly conceived as the actualisation of one possibility among others (which would imply some sphere of potentiality over against God that would count as another factor alongside God), but rather the establishing of a world in which there is such a thing as the actualisation of possibilities. And to go still further and apply the language of decision to God's own triune being is to confuse the (apophatic) principle that there is no constraint or compulsion in God with a (cataphatic) assertion of divine self-creation that

\footnotetext{
${ }^{14}$ In this context, I think McCormack is probably right to take seriously Barth's observation that his mature theology includes 'a little Hegeling'; the question is whether or not it is possible to get away with just 'a little Hegeling' without sending the whole enterprise into a rather too Hegelian direction. See McCormack, Orthodox and Modern, 271.
} 
reintroduces the spectre of the Deus absconditus. ${ }^{15}$ The aim of the rest of this paper is to argue that there is a better way.

\section{The One Who Is Present in Love}

The easiest way to avoid the problematic implications of characterising divine being as decision is to characterise God's being as Trinity, prior to and apart from any decision. Admittedly, Barth himself neither saw nor intended any compromise of his Trinitarianism in his claim that the divine being is decision - though the fierce debate among scholars on the relative priority of Trinity and election in Barth's thought shows at the very least that his language on this question is sufficiently ambiguous to be open to varying interpretations. ${ }^{16}$ In any case, in order to avoid the problems I have identified in Barth's presentation, all the while retaining his improvements over more traditional accounts of the divine perfections, I propose that the Triune God is better characterised as the One who is present in love than as the One who loves in freedom.

\footnotetext{
${ }^{15}$ In defending a decisionistic divine ontology (which, again, I think he is correct to identify as at least implicit in Barth), McCormack writes the following: 'The statement "God would be God without us" is a true statement and has value in safeguarding the divine freedom. To say more than this, however, to say that God would have been this way or that way, is to enter into unwarranted speculation' (Orthodox and Modern, 297; cf. 274). McCormack's warnings here mirror Luther's in The Bondage of the Will against peering behind the Deus revelatus to the Deus absconditus (e.g., 'God must be left to himself in his own majesty, for in this regard we have nothing to do with him, nor has he willed that we should have anything to do with him,' Career of the Reformer III, vol. 33 of Luther's Works, American ed., ed. Philip S. Watson (Philadelphia: Fortress Press, 1972), 139). To be sure, the parallel with Luther is not exact: Luther is talking about how God actually is apart from revelation, while McCormack is referring to how God would be apart from the eternal decision to be the God revealed in Jesus Christ; moreover, McCormack deploys the language of 'eternal decision' precisely to eliminate the gap between divine being and act that he (rightly) finds problematic in theologians like Luther; but affirming that 'God would be God without us' while denying any correspondence between that God without us and the God who is with us seems to reintroduce just that gap by the back door.

${ }^{16}$ Statements of the opposing positions are found in McCormack, Orthodox and Modern, Part 3, and George Hunsinger, Reading Barth with Charity: A Hermeneutical Proposal (Grand Rapids: Baker Academic, 2016). For a fine analysis of the issues at stake, see Kevin W. Hector, 'God's Triunity and SelfDetermination: A Conversation with Karl Barth, Bruce McCormack and Paul Molnar,' in International Journal of Systematic Theology, 7/3 (July 2005): 246-61.
} 
The point of this shift is certainly not to suggest that God's love is other than free, but it is to maintain that Barth's way of distinguishing freedom from love in his treatment of the divine perfections ends up granting the former the very kind of priority over the latter that he wants to avoid. Barth highlights freedom in order to safeguard the distinctiveness of God's love as precisely God's, yet it is open to question whether a separate appeal to divine freedom is needed to achieve this end. Even in the human context it is difficult to conceive of what it would mean to speak of love as other than free: insofar as love is a matter of personal agency, a love that is compelled hardly qualifies as love. At the same time, love's freedom is not a matter of decision, because, as Augustine long ago recognised, we can't choose whom we love; nevertheless, love remains a matter of radical self-commitment that is coherent only as claimed by the one who loves as her own action. Freedom in love is therefore not a function of decision, but rather a matter of experiencing love as the expression of (rather than a constraint on) one's identity.

Because being and act are not identical in humans, we can realise love only as a gift that modifies our being toward others; but for the Triune God it is intrinsic to the divine being. God is love in that the Father loves the Son in giving all that he is to the Son and confirming this in the Spirit, even as the Son loves the Father by glorifying the Father in the same Spirit, with the Spirit rejoicing in - and thereby sharing - the mutual love of the Father and the Son. In short, 'love' is just a summary description of God's concrete existence as three persons. All this is certainly 'free' in that it is not externally compelled or constrained, but not in the sense that it is a matter of decision, as though freedom were the prior condition or ground of divine love; rather, the mutual love of the 
Father, Son, and Holy Spirit is just what it means for God to be free: neither relative to or dependent on any non-divine reality, but simply God's own being as realised in and as three persons. In this way, the confession of God as Trinity suggests how it is both possible and necessary to distinguish the claim that God's being is in act (that is, not logically prior to the love of the persons) from the claim that it is the product of an act (as though the love of the persons followed a logically prior divine decision).

But if, pace Barth, the qualification 'in freedom' does not secure God's love as God's, since freedom is analytic in love, the qualification 'present' does. For love is not necessarily a matter of presence. Indeed, not only is it possible to conceive of love at a distance, but human love is invariably a matter of overcoming distance by drawing distinct individuals together into a relationship of mutual trust and vulnerability. From this perspective, the claim that God's love is a matter of presence helps to answer the objection that relational accounts of divine love like Barth's presuppose just such distance insofar as the language of love implies the movement of one toward another. A divine love interpreted as 'object-related' in this sense would be flatly inconsistent with the Christian conviction that God is one (Deut. 6:4) and not a union of three separate agents. $^{17}$

In order to see how accentuating the divine perfection of presence provides a check against such tritheistic risks, it is important to eschew the term's spatial connotations. The mutual presence of the divine persons is not a matter of their being

\footnotetext{
${ }^{17}$ Though Barth is more typically accused of modalism than of tritheism, I follow Sonderegger (from whom I draw the phrase 'object-related') in seeing the latter as a greater risk in his account of Trinitarian love. See The Doctrine of God, 477-82. Cf. the still more extreme case of Balthasar, who interprets the Father's begetting of the Son as 'the positing of an absolute, infinite "distance" that can contain and embrace all the other distances that are possible in the world', which, in turn, amounts to a "separation" of God from himself'. Hans Urs von Baltasar, The Action, vol. 4 of Theo-Drama: Theological Dramatic Theory, trans. Graham Harrison (San Francisco: Ignatius Press, 1980), 323.
} 
open or available to one another by virtue of proximity. Instead, presence refers to the divine persons' inseparable mutual indwelling - a relationship (designated by the theological term 'perichoresis') that has no creaturely analogue precisely because it prescinds from any thought of ontologically distinct entities (viz., 'individuals') relating to one another. ${ }^{18}$ On a properly Trinitarian understanding of the persons, the Father is present to the Son as the one in whom the Son lives, even as the Father is in the Son as the one by whom the Son lives (John 10:38; 14:10-11; 17:21), and the two are one (John 17:11) precisely in the Spirit who, as the Spirit of sonship (Rom. 8:15; cf. Gal. 4:6), simultaneously confirming both the Son's identity as the beloved of the Father and his love for the Father. So in the Trinity presence is not a matter of the confrontation of distinct subjects, but just the constitution of the one divine life, supremely undivided and indivisible, in threefold repetition. ${ }^{19}$ While presence remains a relational category, the divine persons are (in the language of Thomas Aquinas) subsistent relations, such that they do not subsist independently of one another, and their mutual presence is not adventitious or accidental. ${ }^{20}$

The love in and through which the divine persons are God is therefore not distributed among the persons as among three distinct centres of consciousness. On the contrary (and to put it in the sharpest possible terms), the mutual presence of the persons is a coincidence of consciousness - which is just another way of making the traditional point that in God there is just one will and one agency (opera Trinitatis indivisa sunt!).

\footnotetext{
${ }^{18}$ In order to avoid such an interactive interpretation of perichoresis, Barth helpfully commends the Latin translation circuminsessio (mutual indwelling) over the more literal circumincessio (mutual interpenetration); see Barth, $C D \mathrm{I} / 1,370$.

${ }^{19}$ On this basis Thomas avers that the best creaturely analogy for the Trinitarian processions is 'in the intellect where the action of understanding remains in him who understands'. Thomas Aquinas, Summa Theologiae [hereafter $S T$ ] 1.27.1, 60 vols. (London: Eyre \& Spottiswood, 1964-1981).

${ }^{20}$ See Aquinas, ST 1.29.4, where the Responsio focuses precisely on showing that it is coherent to speak of a relation that is not merely accidental to a subject; cf. the replies to Objections 3 and 4.
} 
Divine love is therefore not a modification of personal existence (as is the case when one human being falls in love with another), but just the mode of the divine persons' coinherence, their being one God in and through one another, such that (for example) for the Father not to be present to the Son would mean (per impossibile) their mutual dissolution as persons. So to affirm that God is eternally present in love specifies the perichoretic character of that love, and is thus is a vital qualification of the affirmation that 'God is love', insofar as it is possible to conceive of love that does not take this form. ${ }^{21}$

This intradivine pattern of presence in love has an external parallel in God's relationship to creatures. Here, too, an emphasis on presence does important dogmatic work in forestalling possible misunderstandings of the character of divine love ad extra. For it is a persistent pastoral problem for Christians that God's love seems distant. It is not obvious that God is present when evil and suffering are near at hand. While we may continue to affirm that God loves us and, indeed, that nothing can separate us from that love (Rom. 8:39), when faced with evil we are sorely tempted to regard God's loving presence as a matter of future hope than as that which defines the contours of our present experience. The fact that we so often fail to flourish as we imagine a loving God intends makes it anything but obvious that the loving God is present with us.

But if God is the one and only antecedent condition of created existence, then the world depends at every moment on God's presence, since no creature can exist except by virtue of God being present to it. ${ }^{22}$ And if this existence is a blessing (and if it were not,

\footnotetext{
21 'In the life of God, love is always deflected from the "object" that would close or satisfy, that would simply be the absent other imagined as the goal of desire; the other is always engaged beyond, engaged with another otherness.' Rowan Williams, 'The Deflections of Desire: Negative Theology in Trinitarian Disclosure', in Silence and the Word: Negative Theology and Incarnation, eds O. Davies and D. Turner (Cambridge: Cambridge University Press, 2002), 121-2.

22 'Now since it is God's nature to exist, he it must be who properly causes existence in creatures, just as it is fire itself sets other things on fire. And God is causing this effect in things not just when they begin to
} 
then its diminishment through suffering and death could not be judged an evil), then it follows this presence is loving and, indeed, occasioned by love. So as within the Trinity the Son is never without the Father's presence as inexhaustibly self-bestowing love, so in God's works ad extra, the world does not exist except as the Father's self-bestowal in the Son is extended outward, as the Father's presence in the Son grounds the Son's presence in the world as the one in whom 'all things hold together' (Col. 1:17). To be sure (and as will discussed further below), this presence remains intractably invisible: we do not see God; but because it is through the divine presence that God sustains creatures in being, it is true both that presence is the mode of God's love of creation, and that love is the ground of God's presence in creation.

This coupling of love and presence as the foundational divine perfections preserves the traditional distinction between God's 'communicable' and 'incommunicable' attributes on much the same terms as Barth's pairing of love and freedom. Within the framework established by the characterisation of God as the One who is present in love, the perfections of the divine love can remain unchanged from Barth's list: grace, holiness, mercy, righteousness, patience, and wisdom. The perfections of divine presence would differ from Barth's perfections of divine freedom only in that freedom is now interpreted in terms of love. Yet this reinterpretation is significant. Barth's freedom, cashed out in the language of decision, is at bottom a freedom to, that is, a freedom whereby God is able to dispose of God's self and the world as God wills (so that it is by virtue of the exercise of divine freedom-as-decision that God

exist, but all the time they are maintained in existence, just as the sun is lighting up the atmosphere all the time the atmosphere remains lit. During the whole period of a thing's existence, therefore, God must be present to it, and present in a way in keeping with the way in which the thing possesses existence.' Aquinas, ST, 1.8.2 (emphasis added). 
has the perfections of unity, constancy, glory, and so forth). By contrast, when freedom is framed in terms of God's presence in love, it becomes a freedom for, stressing not God's ability to do whatever God wants, but God's enabling life through the ungrudging bestowal of being, whether uncreated being within the life of the Trinity or created being in the work of creation.

\section{Divine Presence and Divine Action}

This distinction between freedom to and freedom for can be illustrated by comparing the implications of the prioritisation of presence over freedom for a theological account of divine action. One infelicitous implication of defining God's being as eternal decision is to suggest that God's actions ad extra are a matter of direct causal control, such that whatever happens in the world may be equated with God's will. In Protestant Scholasticism this causal relationship was typically described in terms of God's 'efficient will'. At the same time, because God's indefectible goodness was understood to preclude God's efficient willing of - and thus moral responsibility for evil, the latter was excepted from direct divine enactment and attributed instead to God's 'permissive will' ${ }^{23}$ Obviously, the utility of this later category depends on how divine permission is understood. It evidently does little to absolve God of responsibility if the divine 'permitting' of evil is analogous to my permitting a toddler to play with a loaded pistol. But talk of God's 'permissive will' is arguably best interpreted in more minimalist

\footnotetext{
${ }^{23}$ See, e.g., Johannes Polyander, Andreas Rivetus, Antonius Walaeus, Antonius Thysius, Synopsis Purioris Theologiae/Synopsis of a Purer Theology, volume 1, ed. Dolf te Velde, trans. Riemer A. Faber (Leiden: Brill, 2015 [1625]), 6.34; cf. 11.21-26. Other theologians of this period offer a more variegated account of divine willing. Quenstedt, for example, added impeditio (God's blocking of creatures' evil intentions) and directio (God's channeling of creaturely activity) to the categories of permissio and determinatio, but these gradations arguably only worsen the anthropomorphism in accounts of God's providential activity by suggesting varying degrees of divine proximity to creaturely events. See J. A. Quenstedt, Theologia Didactico-Polemica, $4^{\text {th }}$ ed., (Wittenburg, 1701), 1.533-34; cited in Charles M. Wood, The Question of Providence (Louisville, KY: Westminster John Knox, 2008), 88.
} 
fashion, that is, not as providing a descriptive model of how God relates to evil, but rather as a means securing two basic points: first, that God is not the agent of evil (that is, the occurrence of evil must be distinguished from God's willing it), and, second, that evil nevertheless remains subject to divine sovereignty (that is, evil is within the compass of God's willing and thus of God's power to redeem). In any case, the restriction of the category of permissive will to the problem of evil means that worldly events are normally explained as the consequence of God's efficient willing, with only a small subset excepted. If anything, Barth's emphasis on divine freedom as decision only exacerbates this tendency, since in the account of nothingness in Church Dogmatics III/3 even evil turns out to be the product of God's efficient will, albeit indirectly. ${ }^{24}$

Yet if God is understood as the One who is present in love, it is the category of permissive will that turns out to be the more appropriate for characterising God's typical relationship with worldly occurrences, while God's efficient willing applies only to a restricted set of cases. For whereas the language of decision naturally corresponds to a model of divine action in which God manipulates creatures to achieve certain ends, the language of presence suggests a form of divine action that (in the words of PseudoDionysius) 'preserves and embraces the world.... founds it .... makes it secure.... [and] holds it together'. ${ }^{25}$ Because this work is (as Paul notes in Rom. 1:20) inherently invisible, the divine presence is perceptible only when God determines to reveal it, whether through miraculous signs (e.g., the burning bush), prophetic visions, or -

\footnotetext{
${ }^{24}$ In defining evil as 'nothingness' (das Nichtige), Barth depicts it is that which God does not will, but which (by virtue of the sheer power of God's not willing) acquires a weird form of existence, so that in a "way of its own nothingness "is"'. See Barth, $C D$ III/3, 349 .

${ }^{25}$ Pseudo-Dionysius, Divine Names, 10, in Pseudo-Dionysius: The Complete Works, trans. Colm Luibheid (New York: Paulist Press, 1987), 119. Jean-Pierre Batut notes that it was a general feature of patristic thought to understand God's almightiness as matter 'd'embrasser et de circonscrire'. See his Pantocrator: «Dieu le Père tout-puissant» dans la théologie prénicéenne (Paris: Institut d'Études Augustiniennes, 2009), 491.
} 
definitively - in the life of Jesus. On these occasions the divine presence becomes visible in that God, though still veiled in creaturely form, nevertheless discloses God's self as the immediate subject of an event. That is, we say God spoke to Moses through the burning bush, that God confirmed God's presence to Gideon through the wet (and then dry) fleece, and that God lived among us as Jesus of Nazareth. Insofar as God makes God's presence known as agent in these events, in such cases it is appropriate to speak of God's efficiently willing that the bush should burn, that the fleeces should be wet (or dry), and that Lazarus should be resuscitated.

But what about elsewhere? To be sure, because every creature is entirely dependent on God for its existence in every aspect and at every moment of its existence, it is both possible and fully appropriate to say that God is the cause of all worldly events. The problem is that when the language of decision and efficient willing governs theological interpretation of God's relationship with creation, the language of divine causation all too easily suggests that God's causal activity displaces that of creatures, making them purely instrumental to God. And that is a mistake, if (as Christians hold) God has created a world with its own internal causal processes that permit worldly events to be explained in terms of created causes. Under those conditions, it is entirely right that we do not normally describe our quotidian experiences as caused by God, for while God is indeed (in the language of the Scholastics) the 'primary' cause of every occurrence, sustaining and empowering creatures as they exercise their proper powers to produce worldly effects, quotidian events (unlike the burning bush, Gideon's fleece, or Jesus' life) are fully explained in their created reality by reference to these created, or 'secondary', causes alone, without any need to refer to God. 
The (secondary) causal powers of creatures are diverse. Some creatures affect others through physical laws operating with a mathematical regularity that makes their effects in varying degrees predictable. Other creatures - chiefly ourselves, but also (traditionally) angels and (possibly) undiscovered extra-terrestrial life forms - produce effects freely rather than according to physical laws, and these effects include both morally good and evil deeds. ${ }^{26}$ Finally, if the Copenhagen interpretation of quantum mechanics is correct, there are still other events that are genuinely indeterminate: that is, they lack an identifiable secondary cause, and so are genuinely (that is, ontologically rather than merely epistemologically) random.

It is in recognising the dissimilarity of these causes while at the same time affirming that they are all equally sustained and empowered by God as primary cause that the general application of the category of permissive will shows its value. For because all these secondary causes are equally dependent on God, it is problematic to view any one type (say, the good or evil effects of creaturely freedom) as any more mysteriously related to God's sovereign presence than any other (say, the operation of gravity). Quite the contrary, insofar as physical laws are every bit as real as human freedom, the process by which God as Creator 'causes' the movement of planets or the oxidation of iron is no less opaque to us than the means by which God effects God's will through the free decisions of rational creatures. As primary cause, God's relationship to all created events is equally direct (the point of affirming the distinction between primary and secondary

\footnotetext{
${ }^{26}$ I would describe my position on the freedom of the will as a form of compatibilism, but it is a specifically theological compatibilism and, as such, is distinct from the compatibilism of philosophers in the line of Hume. That is, I do not claim that the actions of human beings are in principle explicable in terms of secondary causal processes (and thus determined in a materialist sense); that is the point of my distinguishing the effects of creaturely willing as a distinct form of secondary causation from the operation of natural law. At the same time, I want to insist that acts of creaturely willing (along with the 'uncaused' events of the quantum world) are no more independent of God than the most deterministic of physical processes.
} 
causation is not to imply that creatures are independent of God), but in terms of our apprehension also equally mysterious, precisely because all we see is the operation of created causes that are in themselves perfectly adequate to explain the occurrence of quotidian events. As a matter of faith, we trust that God is present in love at every point in the continuum of creaturely occurrence - indeed, that this presence is the condition of the possibility of there being any such occurrences at all - but how God makes it that some things should happen by physical law, others freely, and others randomly is not accessible to us. ${ }^{27}$

The epistemic opacity of the world with respect to God's operation as primary cause renders the general application of the language of 'efficient willing' unhelpful, because its connotations do not honour the equally mysterious character of God's relation to all forms of secondary causation. To speak of God 'efficiently willing' that the moon orbits the earth or that an acorn becomes an oak might seem appropriate insofar as we think of God's action as analogous to our putting a satellite into orbit or planting a tree, but such parallels are profoundly false, because the integrity of created causes means that the world is not properly envisaged as 'a machine operated by divine controls' ${ }^{28}$ It follows that in the same way that to speak of God 'efficiently willing' that I should go to the store or write this paper grates against our sensibilities, since it is hard to imagine how God can will that I do such things without evacuating my willing of any real causal role, so, too, should the language of God's efficiently willing that the sun should rise tomorrow. The language of permissive will is more appropriate, precisely because it

\footnotetext{
${ }^{27}$ The best analogy (associated with Austin Farrer, but subsequently deployed by many others, including Rowan Williams, as cited in note 28 below) is probably the way in which the author of a novel is the 'primary cause' of every event in her book, though some of the narrated events occur by physical law, others by the characters' free decisions, and so forth.

${ }^{28}$ Austin Farrer, The Glass of Vision (Westminster: Dacre Press, 1948), 4.
} 
secures with respect to all manner of everyday creaturely occurrence the same two points for which it was traditionally invoked in relation to evil: first, a distinction between the operation of created causes and God's agency as primary cause (so that to say ' $x$ happened' is not equivalent to saying 'God did $x$ ', except for the subset of events - divine revelation - in which no secondary cause stands between God and $x$ ), and, second, the affirmation of God's sovereignty over all events (so that the refusal to equate ' $x$ happened' with 'God did $x$ ' does not imply that $x$ happened apart from God's will).

In short, the language of permission allows God's presence to and power over all created reality to be affirmed alongside the reality of secondary causes, with the latter understood as qualitatively distinct from God as primary cause. This broad application of the permissive will is not alien to Scripture, where at the very beginning of the biblical narrative, the work of creation itself is described in just such terms: God says, 'Let $x$ be', and $x$ comes into being. While I do not want to place too much metaphysical weight on this Hebrew idiom, it is helpful as a way of loosening up our tendency to focus on the (sinful) acts of free creatures as the sole arena where the language of divine permission has a place. Again, when permission is restricted to that sphere, it becomes easy to assume that God's causal relationship to other worldly events is transparent, and that it is only when the question of freedom emerges that God's agency as Creator poses problems for a coherent affirmation of the integrity of created being. The language of permissive will, by contrast, allows an unqualified affirmation that no happening is outside of God's will without suggesting that God's willing as primary cause is in any case - including the operation of physical laws - analogous to running a machine. ${ }^{29}$

\footnotetext{
${ }^{29}$ Notwithstanding her reluctance to speak of God as cause, Sonderegger gestures in this same direction with her remarks on God's 'jussive' willing in Genesis 1 (cf. Sonderegger Doctrine of God, 177,
} 
The language of permission does not give us a clear sense of how God sustains and empowers creatures. Indeed, one advantage of deploying 'permissive will' in this context is that it highlights the essentially mysterious character of God's action as primary cause and the corresponding lack of any clear analogy for such action in the creaturely sphere. Appeal to God's permissive will does not suggest that God's relationship to any one particular type of creaturely event is more or less transparent than any other. Insofar as all creaturely occurrences are sustained by God, none is outside the scope of God's redeeming power, but beyond that we can - and therefore should - say very little. ${ }^{30}$

To apply the category of divine permission globally, as descriptive of the way God typically relates to all created reality, affirms that God established a world that in its createdness has its own integrity. Stars and rocks and plants are no more puppets on a string than we are. They operate according to their own created laws, which are just as opaquely correlated with divine purposes as the acts of creatures that act freely, or quantum events that occur randomly. Because talk of God's action in terms of decision tends to cast providence as a matter of efficient willing, it collapses the space between divine will and created effect; by contrast, talk of God's presence surrounding and sustaining the world is more suggestive of permissive willing, in which created effect

\footnotetext{
302). This is quite different from John Macquarrie's idea that 'letting be' is the mode of divine existence (rather than action), which leads him to conclude that 'it is of [God's] very essence to create'. John Macquarrie, Principles of Christian Theology, Revised ed. (London: SCM Press, 1977), 118, cf. 121.

${ }^{30}$ The analogy of the writer may again be helpful here, insofar as novelists report that the proper development of characters requires that the author 'allow' them to assume their own contours or follow their own path over the course of the narrative. The use of 'permission' in this case is as restrictive as in that of God over against the world: since the author remains the sole cause of any character's activity, there can be no genuine ontological independence of the character with respect to the author's will (at least, absent the intrusion of another author or editor into the process). Yet the parallel does suggest something about how the language of permission can function to give due weight to the integrity of secondary causes. Cf. Rowan Williams, Dostoevsky: Language, Faith and Fiction (New York: Continuum, 2010), 234.
} 
cannot be traced with the same epistemological immediacy to divine will. To be sure, nothing occurs apart from the will of God, but how God's willing brings it about that anything should occur (the shape of what Austin Farrer once characterised as the 'causal joint' between God and the world) is not open to us. What Christians can and must affirm is that in all that happens (and however it happens), God is present in love: for since the presence of the Creator is necessary for anything to happen at all, and since this God 'desires everyone to be saved and to come to the knowledge of the truth' (1 Tim 2:4; cf. Ezek 18:23, 32; 33:11), the divine presence cannot be other than loving.

\section{Conclusion}

In his effort to affirm that the God who encounters us in Jesus is none other than the one, true God, Karl Barth affirmed God's being in act. There is no God behind the God who discloses God's self to us in Christ, no eternal divine essence distinct from the temporally experienced reality of divine existence; rather, because 'God's being is decision', we can trust that the good news proclaimed by Jesus is just the will of God. And yet although the content of this good news is precisely God's eternal and unshakeable love for us, the claim that this love is rooted in divine decision effectively gives freedom priority over love in Barth's divine ontology in a way that Barth himself clearly did not want, leading me to conclude that Barth's prioritisation of freedom understood in terms of the activity of decision rather than the more 'apophatic' doctrine of aseity - among the divine perfections is to be avoided. In its place, I have proposed presence as a better qualifier of the divine love, replacing Barth's summary characterisation of God as 'the One who loves in freedom' with 'the One who is present in love'. 
One advantage to this revision of Barth is that presence, unlike freedom, is not analytical in love. Love might be distant, and, indeed, one objection to Barth's own Trinitarian interpretation of divine love is that its relational character implies some sort of distance between the persons (if only the logical 'distance' of subject to object) that tends toward tritheism. Similarly, our experience of a world that operates under its own laws without any clear regard for the flourishing of particular creatures can make it tempting to view God's love of creation as distant from the world: genuine, perhaps, but operating at some remove from the rough-and-tumble of daily events. The language of presence blocks this temptation. Moreover, where the language of decision risks collapsing God's being and God's creating into a single act, the language of presence, while maintaining a strong correspondence between the (loving) relations of the persons in the Trinity and God's (loving) relation to the world as Trinity, does not identify them. So, even as God is the Trinity willingly (that is, precisely as love), without the Trinity being a product of divine decision, so also to speak of God's willing of creation in terms of God's permission allows the world to be conceived as the product of God's love without collapsing the relationship between God's will and worldly occurrence. To be sure, the world is logically subsequent to God's willing as the Trinity is not, but in both cases willing is a matter of presence rather than decision. ${ }^{31}$

\footnotetext{
${ }^{31}$ Does this distinction between Trinitarian letting be ad intra and creative letting be ad extra entail a gap between being and act in God? Not in the sense that it precludes the claim that God's decision to be Godfor-us is an eternal decision, such that God has 'never' (to fall into the unavoidable temporal language) willed to be anything other than God-for-us. But there remains a logical gap between God's being triune and God's willing to be God-for-us that is unavoidable, so long as one concedes that 'God would be God even without us'. Against the charge that positing such a gap introduces its own Deus absconditus, I would reply that to claim that Jesus is the eternal Word made flesh is precisely to affirm that there is no Deus absconditus behind the God revealed in Jesus; indeed, that is just the meaning of 'incarnation' and the content of the good news - that this is who God is eternally. God did not have to become incarnate, but insofar as the love shown forth in incarnation and creation reflect the love by which God is God eternally, there is no basis for the charge of divine arbitrariness here. As Jesus pointed out long ago, we have no
} 
Since the advent of Derridean deconstruction, the concept of 'presence' has acquired a bad reputation. Presence, it is argued - and especially the immediate presence of God - makes it impossible to take difference seriously. It breeds a sterile and oppressive monism, since the presence of a God who is the source and end of all that is inevitably eclipses everything else and becomes the only reality worthy of attention. By contrast, the force of my argument here is that divine presence, far from erasing difference, is its ground, both within the Trinity and in the Trinity's relationship to the world. Within the Godhead the personal presence is manifest in the threefold form of the divine life through the inseparable relations of each one with the other two. One person does not subsume the others; neither do the three compete for a common space; rather, each sustains the others in and through its presence in them in love: the Father by begetting the Son in the Spirit, the Son by receiving the Father's gift of divinity in the same Spirit, and the Spirit, as the Spirit of the Father and the Son, as inseparable from either. In creation likewise God's presence does not come at the expense of creatures' integrity, but is its basis. For because God creates from nothing, it is only as present in creation at every point and every moment that creatures come to be and are sustained in their difference from God and one another.

It is very much the case, however, that it is a condition of creatures' integrity that the divine presence in the world is hidden. As Paul notes, God's nature and power are inherently invisible, such that God's presence is not an immediate object of creaturely experience in light of which phenomena may be explained, but is rather the hidden cause that enables creatures to deploy their own proper powers in relation to one another. It 
follows that God does not need to be absent in order for creatures to come to be, as though the price of creation were a constriction of divine presence; yet God is properly hidden, for because God's work as Creator is just that of causing existence in creatures, God is not present as an existent alongside creaturely existents, or a cause alongside created causes. In other words, God's presence is hidden precisely in its allencompassing character. Even where God reveals God's presence, first in the history of Israel and then, definitively, in the person of Jesus of Nazareth, God is perceived only indirectly - unveiled (as Barth rightly insisted) only through the veil of created reality that is sustained by God as other than God.

In this sense, it is important to honour the intent behind Barth's actualism. For divine presence is not a static 'being', but always a loving 'being there', the inescapability of which is, for those with eyes to see and ears to hear, pure grace:

Where can I go from your spirit?

Or where can I flee from your presence?

If I ascend to heaven, you are there;

if I make my bed in Sheol, you are there.

If I take the wings of the morning and settle at the farthest limits of the sea, even there your hand shall lead me, and your right hand shall hold me fast. (Ps. 139:7-10)

We do not see God active everywhere, nor do we have the need to invoke divine presence as an explanatory principle for worldly phenomena, yet as Creator God sustains the world in love by letting it be. And for this reason, the divine presence is never known by our 
coming upon God like a tree in the woods, but only in God confronting us when and as God chooses. And so when God does confront us, whether on a mountain top, in a gossamer puff of fleece, or in Jesus, we encounter One who is present in love. To be sure, because this encounter always breaks on us unexpectedly within the everyday course of events in which God's presence and power are normally unseen, it also comes as a shock, and as a judgment of our failure to live lives worthy of the gift we have been given. And yet on the basis of how God shows God's self to us, we also affirm that in every circumstance, the Father who is eternally present in and with the Son and the Spirit is present also with us in love. ${ }^{32}$

\footnotetext{
${ }^{32}$ An earlier version of this essay was presented as the 2016 Colin Gunton Lecture at King's College London.
} 